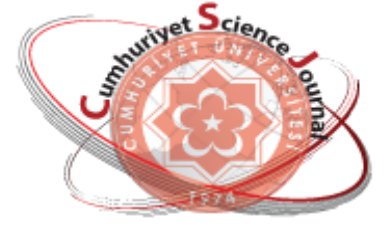

e-ISSN: $2587-246 X$

ISSN: 2587-2680

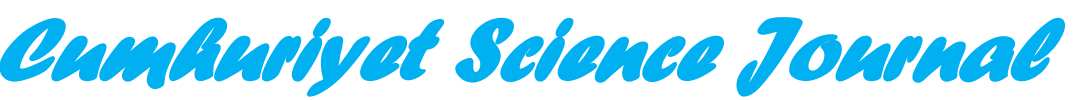

CST

Cumhuriyet Sci. J., Vol.39-3(2018) 628-634

\title{
Decontamination of Liquid Radioactive Wastes Using Clay Minerals
}

\author{
Mehmet TEKDAL \\ Çukurova University, Faculty of Education, Department of Computer Education \& Instructional Technology, \\ Adana, TURKEY
}

Received: 16.02.2018; Accepted: 27.06.2018

http://dx.doi.org/10.17776/csj.395916

\begin{abstract}
The rapid increase in the use of nuclear energy and radioisotopes has necessitated the development of effective and economic methods for the decontamination of radioactive wastes. In this study, the decontamination of low-level radioactive wastes containing ${ }^{137} \mathrm{Cs}$ radioisotope were investigated by using clay minerals. The clay samples used as activity absorber materials were obtained from the clay deposits in the various regions of Turkey (Adana, Konya, Diyarbakır).The columns input and output concentrations were determined with radiometric methods by using a gamma $(\gamma)$ spectrometer. According to the results of this investigation, "smectite" type Turkey clays were found to be suitable for the decontamination of radioactive wastes containing radioactive cesium.
\end{abstract}

Keywords: Radioactive Wastes, Clay Minerals, Cesium, Ion Exchange, Decontamination.

\section{Sıvı Radyoaktif Atıkların Kil Mineralleri ile Aktiviteden Arındırılması}

Özet. Nükleer enerji ve radyoizotopların kullanımındaki hızlı artış, radyoaktif atıkların aktiviteden arıtılması için etkili ve ekonomik yöntemler geliştirilmesini gerektirmektedir. Bu çalışmada, ${ }^{137} \mathrm{Cs}$ izotopunu içeren düşük aktiviteli radyoaktif atıkların, killer yardımıyla aktiviteden arındırılması incelenmiştir. Aktivite tutucu materyal olarak kullanılan kil örnekleri Türkiye'nin çeşitli yörelerindeki (Adana, Konya, Diyarbakır) kil yataklarından sağlanmıştır. Kolon giriş ve çıkış derişimleri, gama $(\gamma)$ spektrometresi kullanılarak radyometrik yöntemle saptanmıştır. Bu araştırma sonuçlarına göre "smektit” türündeki Türkiye killer radyosezyum içeren radyoaktif atıkların arıtılması için elverişli olduğu bulunmuştur.

Anahtar Kelimeler: Radyoaktif Atıklar, Kil Mineralleri, Sezyum, İyon Değiştirme, Radyoaktiviteden arındırma.

\section{INTRODUCTION}

Radioactive wastes are wastes containing radioactive substances which arise as a result of the use of radioactive substances for various purposes. It is of great importance for environmental health that these wastes are cleaned and neutralized without polluting the environment. The problem of the control of radioactive wastes emerging in hospitals, factories, research centers and increasing numbers of nuclear power plants is becoming increasingly important [1].
Radioactive wastes that can be found in solid, liquid and gaseous form can be classified into low (<10-5-1 Ci / 1, kg), medium (10-5-1 Ci / 1, kg) and high level (> $1 \mathrm{Ci} / \mathrm{l}, \mathrm{kg}$ ), respectively [2]. Since radioactivity cannot be completely removed, it is ensured that the radioactive nuclei in the wastes are collected in a small volume by a suitable method and separated from the large amount of waste. Thus, the cleaned waste can be safely thrown away.

The main methods used for this purpose are evaporation, biological, chemical and ion 
exchange methods [3].Particularly one of the most suitable methods for efficiency and volume reduction is ion exchange. One of the advantages of this method is its ease of application and automatic remote control of the system [4]. Because of their abundance in the nature, ease of regeneration, resistance to heat and radiation, many naturally occurring organic and inorganic substances can be used to a large extent in the process of ion exchange [5].

Most of the wastes are in the form of liquid solutions containing radioactive contaminants in ionic form. The goal in the treatment of radioactive waste is to remove these ions from the solution and isolate them in a massive and immobile manner. For this reason, there is a need for substances to enter ionic reactions with radioactive nuclei. Furthermore, the compound formed as a result of such a reaction must be insoluble in the waste solution.

The most common radioactive nuclei encountered in wastes are alkaline classes such as Cs137 and $\mathrm{Sr} 90$. Therefore, the materials to be used for waste disposal must be ionic additions that can form insoluble compounds with alkali and alkaline soil cations. For these reasons, clay minerals, a natural ion exchanger, are useful for cleaning radioactive waste. The ability of the clays to retain radioactive substances depends on the structure of the clay and the processing conditions.

Studies in Turkey have been done for the use of nuclear energy and these studies have come to the stage of establishing a nuclear power plant. Currently, significant quantities of radioisotope are used in hospitals and research centers. For this reason, it has become compulsory for Turkey to carry out necessary studies on the cleaning and control of radioactive wastes. In this context, the main objective of this study is to investigate the removal of the activity of radioactive waste with clay samples obtained from clay deposits in various regions of Turkey. Thus, both the development of one of waste removal method and determining of the availability of clays in Turkey for this purpose will be researched [1].
Ion exchange is the exchange of ions formed at the boundary of a solid particle and liquid. Ion exchange studies have started with Aristodle, which uses sand filters to treat sea water and contaminated water [4]. In the early 19th century, ion exchange events were uncovered by $\mathrm{Sir}$ Humphrey Davy, Lumbuschini, Huxtable, Liebig, Thompson, Graham, Expirit and Fuchs. The most important work on the ion exchange phenomenon was carried out by Thompson. In Thompson's work, the calcium ammonium ions was studied the ion exchange with the soil and found that the exchange had an equivalent amount; the soil aluminosulfates are the basis for ion exchange and heat treatment destroyed the ion exchange ability of silicates [6].

Lemberg in the second half of the nineteenth century showed that the ion exchange phenomenon is stoichiometric and reversible. Lemberg and Wiegner [7] have developed structures of natural ion exchangers. Harm then used ion exchange methods to remove sodium and potassium from the sugar beet water. A few years later, Harm and Rumpler produced the first synthetic ion exchanger [4].

In studies conducted by Pauling [8], Hendricks [9], Grim [10], and Bacon [11] at the beginning of the 20th century, it was concluded that the ionic exchange properties of natural occurrences were related to the crystal structure of the material.

In 1935, Adams and Holmes [7] synthesized highcapacity sulphonic acid type cation exchangers and polynomine type anion exchangers. In 1950, the kinetic and electrochemical aspects of the phenomenon were clarified, together with all possible technological applications of ionexchange membrane synthesis [12]. The volume of literature on ion exchange has increased rapidly since 1940. This increase reached its highest value between 1950 and 1955 [13].

One of the first applications of the ion exchange phenomenon in the removal of radioactive waste activities was carried out by Ayres [14] in 1951. In this study, high decontamination values were reached with synthetic and organic resins. This 
was followed by studies by [15] that suggested the removal of low-activity wastes. Nuclear sulphonic-polyester type resins were used in fixed bed columns in these studies.

Lacy [16] obtained Oak Ridge clay consisting of montmorillonite and kaolinite with radioactive wastewater to separate radioactive materials and fission products such as $\mathrm{Ce}^{141}, \mathrm{Ce}^{144}, \mathrm{Zr}^{95}, \mathrm{Nb}^{95}$, $\mathrm{Ba}^{140}-\mathrm{La}^{140}$ and $\mathrm{Sr}^{90}-\mathrm{Y}^{90}$

In $1956,1 \mathrm{ft}$ diameter columns bearing strong acid cation resin were started to operate in Los Alamos [6] to remove $\mathrm{Sr}^{89}$ and $\mathrm{Sr}^{90}$ from industrial wastes. In addition to the ion exchanges property of different column applications, the advantage of lignite being easily burned into ash after being saturated with activity.

After the early studies summarized above on the removal of activity from radioactive wastes, a lot of research and application have been going on. Because clay minerals are among the most important sorbent of radioactivity, studies carried out with clay minerals have an important place in these studies. The most important reasons why clay minerals are used in the treatment of radioactive substances are because of their negative charge, large specific surface area and surface hydroxyl groups [17].

According to Rani and Sasidhar [17], different clay minerals show different adsorption capacities for radioactivity. Clay minerals have a high specific surface area allowing strong physical and chemical interactions with liquids. This property results in dissolved species which are subjected to electrostatic repulsion, adsorption or specific cation exchange reactions.

Like clays, a wide range of materials are available for the ion exchange treatment of radioactive liquid wastes. These materials can be grouped as (a) natural ion exchangers such as clays, zeolites, cellulose, charcoals, collagen and (b) synthetic materials such as zeolites, hydrous oxide gels of metals or organic resins. With using these materials, ion exchange processes can be operated in batch or continuous modes. If the wastes contain high concentrations of salts, solids, organic or other contaminations the liquid wastes have to be pretreated before used in exchange process [18].

\section{MATERIALS AND METHOD}

Naturally occurring inorganic materials to be used in waste treatment are usually found in large blocks. These blocks are crushed, ground and sieved. It is necessary to wash with plenty of water in order to get rid of the dust they get during these operations. If the amount of material is high, hydrocyclones are used to separate very fine particles (powders).

The materials are treated with strong mineral acids such as sulphonic and phosphoric acid, alkali hydroxides or salt solutions to increase the holding capacities. This process is known as activation. Aluminum and iron oxides with low holding capacities, for example, are treated with phosphoric acid and the cation-trapping capacities of hydroxide-phosphates are increased. In some cases, the material does not react with the acid anion. However, it is an acid-soluble component. For example, concrete treated with concentrated $\mathrm{HCl}$ will degrade aluminosilicates, aluminum chloride, and silica. When dilute acids are used, the aluminosilicate structure is not completely degraded, but the basic cations are replaced by hydrogen. Such processes are also useful in removing unwanted impurities in the structure.

Specific surface areas grow as materials are passed through heat pretreatment. This situation causes the holding capacities of the materials to increase. The radioactivity of solid materials largely depends on the specific surface area size, which is influenced by the degree of structural impairment. At the same time, materials with large specific surface area can be prepared by milling the materials into very fine particles or by providing liquid supersolids. These precipitates are dried to obtain the active substances. However, the activity of these substances diminishes over time. 
In most waste solutions, radioactive ions are cations. sufficient decontamination is therefore achieved by using cation exchange columns in single or in series. If the waste volume is low, the mineral exchange columns are used to remove the cations and discarded when they become saturated are much more economical than they are regenerated. The column method gives advantages due to advantages such as ease of use and automatic operation [19].

In this study, in order to prepare the artificial waste solution, ${ }^{137} \mathrm{Cs}$ isotope, was provided from the Çekmece Nuclear Research Center, Health Physics Department. Five different clay samples were used as waste retaining material. These samples were taken are given below:

No: 2: Cukurova University, Faculty of Agriculture, Department of Soil Science (from Çukurova region)

No: 3: Konya M.T.A. From the Regional Directorate (Çomaklar senior level - Konya)

No: 7-10: Çukurova University, The Faculty of Engineering, Department of Geology (7- Söğüt, 10- Sögütlü)

No: 19: Çınar - Diyarbakır

IR spectrum of clay samples were taken to analyze the structure of these samples. When these spectrum were compared with the standards $[20,21]$. It was determined that number 2 and number 7 samples are Kaolinite and other clay minerals are smectite group clays [22, 23].

The construction of these clay samples consists of octahedral and tetrahedral strata [24]. An octahedral layer of Montmorillonite is found between two tetrahedral layers. Kaolinites are tetrahedral layers placed on octahedral layers. .In all experiments, the ability of clay minerals to adsorb activity was investigated by means of fixed bed and single column system.

Clay samples used as a holding medium were crushed after passing through a sieve and then washed with plenty of tap water to remove dust and other contaminants from the process. Fountain water is rich in ions used for the purpose of saturating the fleece and to increase the ion exchange capacity. The washed samples were filtered on a filter paper and then the samples were dried at $110^{\circ} \mathrm{C}$ for 3 hours and finally weighed.

These samples were allowed to stand in water for 24 hours before being placed in the collar to allow air bubbles to exit and the hives to swell. First, glass wool was placed at the bottom of the column. Then, it was slowly poured into the column. The column prepared in this way is mounted on the column bearing the waste solution, with a small amount of water at the top, and the liquids are contacted to prevent air bubbles in between.

The adsorption capacities of clay samples were determined by radiometric method. For this purpose, column inlet and outlet activity measurements were made by $\gamma$ - spectrometry. In all experiments, background and sample counting times were counted by taking $5 \mathrm{ml}$ samples.

\section{RESULTS AND DISCUSSION}

In this study, the decontamination of low-level radioactive wastes containing ${ }^{137} \mathrm{Cs}$ radioisotope was investigated by using clay minerals. The distribution coefficient $\left(\mathrm{K}_{\mathrm{d}}\right)$ is a parameter used to determine the ratio of ions adsorbed to the solid to the ions in the liquid phase [25]. The results of these experiments were used to calculate the distribution coefficients for the adsorption of cesium on clay minerals. The distribution coefficients were calculated by the following formula [26].

$$
K d=\frac{f s}{(1-\mathrm{fs})} \cdot \frac{V}{\mathrm{M}}
$$

where, $K_{d}$ is the distribution coefficient, fs is the fraction of cesium adsorbed, $\mathrm{V}$ is the volume of the solution in milliliters, and $\quad M$ is the mass of the clay in grams. In order to show the relation between the distribution coefficients, the amount of cesium adsorbed per unit weight of clay, and the equilibrium cesium concentration in 
solution, this equation can be transformed as given below;

$$
f s=\frac{(C s x)}{\left(C s^{0}\right)} \cdot \frac{M}{\mathrm{~V}}
$$

and

$$
(1-f s)=\frac{(C s)}{C s^{0}}
$$

So, $K_{d}$ can be written as

$$
K d=\frac{(C s X)}{C s}
$$

where CsX is the amount of cesium adsorbed per unit weight of clay, $\mathrm{Cs}^{0}$ is the concentration of cesium in the original solution, and $\mathrm{Cs}$ is the concentration of cesium in the equilibrium solution.

Using these given formulae, we calculated our distribution coefficient values. The results are summarized in Table 1. In Table 1, sample no and distribution coefficient (ml/gr) are given in first and second columns, respectively. As can be seen from Table 1, the distribution coefficient values for clay samples are calculated to be $48.15 \mathrm{ml} / \mathrm{gr}$ for sample No.2, to be $642.59 \mathrm{ml} / \mathrm{gr}$ for sample No.10, $52.46 \mathrm{mg} / \mathrm{gr}$ for sample No.7, to be 513.27 $\mathrm{ml} / \mathrm{gr}$ for sample No.19, and to be $380.92 \mathrm{ml} / \mathrm{gr}$ for sample No.3.

According to these research findings, samples No. 10,19 and 3 are clay samples with the highest activity adsorbents. IR analyzes have shown that these clays are smectite group clay minerals.

Table 1. Distribution Coefficients for Clay Samples.

\begin{tabular}{cc}
\hline SampleNo. & Dist. Coeff. (ml/gr) \\
\hline 2 & 48.15 \\
10 & 642.59 \\
7 & 52.46 \\
19 & 513.27 \\
3 & 380.92 \\
\hline
\end{tabular}

The selectivity of the smectite group clay minerals for ${ }^{137} \mathrm{Cs}$ is due to the fact that the odd and divalent ions in the wick change with the $\mathrm{Cs}+$ ion in addition to physical adsorption. Additionly, the Cs+ ion is large in ionic mobility, as it has the smallest hydrate radius $(2.28 \AA)$ and the number of hydrides $(\sim 9.9)$ in group I ions. For this reason, the ion exchanger is held in great force (Coulomb Force) by the material.

Consequently, according to the results of this study, it was seen that the clay minerals had significant radioactivity retention capacities. This naturally raises the question of clay deposits in Turkey may be store radioactive wastes and can threaten human health. For this reason, it is important to prepare maps that will reveal the radioactive contamination of existing clay deposits. In this respect, it is recommended to carry out new studies in this direction [27].

Turkey is in the process of being set up in an area of nuclear reactors. For this reason, radioactive liquid waste decontamination, at least in terms of the reduction of operational waste treatment and disposal costs is an important issue. In this study, it was observed that clay minerals are an important conservator in the handling of liquid radioactive wastes and can be used in this direction. However, these wastes must be solidified in order to save space and safely store them. In this context, new methods can be researched for the solidification of clay includes radioactive waste.

\section{REFERENCES}

[1]. Yildırım M. and Örnek İ., Enerjide son seçim: Nükleer enerji, Gaziantep University Journal of Social Sciences. 6-1 (2007) 3244.

[2]. Fox C.H., Radioactive wastes. US Atomic Energy Commission, Division of Technical Information; 1965.

[3]. Manning W. M., Radioactive Wastes: Their Treatment and Disposal. Journal of the American Chemical Society, 84-2, (1962) 315-315.

[4]. International Atomic Energy Agency, The Management of Radioactive Wastes Produced by Radioisotope Users, Safety Series. 1965, No.12, IAEA, Vienna. Available at :https://gnssnqa.iaea.org/Superseded\%20Safety\%20Stan 
dards/Safety_Series_012_1965.pdf.

(Sample reference of online book chapters found in websites).

[5]. Senel S. and Senvar C., Decontamination of radioactive wastes by ion exchange. ChimicaActaTurcica, 9-1, (1981) 149-161.

[6]. Kunin R. and Preuss A.F., Characterization of a boron-specific ion exchange resin. Industrial \& Engineering Chemistry Product Research and Development, 3-4, (1964) 304-306.

[7]. International Atomic Energy Agency, Operation And Control Of Ion Exchange Process For Treatment Of Radioactive Wastes. Technical Report Series,78 (1967), IAEA, Vienna.

[8]. Pauling L., The sizes of ions and the structure of ionic crystals. Journal of the American Chemical Society.49-3, (1927) 765-790.

[9]. Hendricks S. B., Lattice structure of clay minerals and some properties of clays. The Journal of Geology, 50-3, (1942) 276-290.

[10]. Grim R. E., Modern concepts of clay materials. The Journal of Geology, 50-3, (1942) 225-275.

[11]. Bacon R. C., A Study of the Laws Governing the Cation-exchanging Properties of a Precipitated Aluminum Silicate. The Journal of Physical Chemistry, 40-6, (1936) 747-61.

[12]. Kressman T. R., Ion exchange resin membranes and resin-impregnated filter paper. Nature, 1950 165-4197, (1950) 568568.

[13]. Kunin, R. and McGarvey F.X. Ion Exchange, Industrial \& Engineering Chemistry, 45-1, (1953) 83-88.

[14]. Ayres J. A., Treatment of radioactive waste by ion exchange. Industrial \&Engineering Chemistry, 43-7, (1951) 1526-31.

[15]. Loewenschuss H., Metal-ferrocyanide Complexes for the Decontamination of Cesium from Aqueous Radioactive Waste. Radioactive Waste Management, 24 (1982) 327-341.

[16]. Lacy W.J., Decontamination of radioactively contaminated water by slurrying with clay. Industrial \& Engineering Chemistry, 46-5, (1954)10611065.

[17]. Rani R.D. and Sasidhar P., Sorption of cesium on clay colloids: kinetic and thermodynamic studies. Aquatic geochemistry, 18-4, (2012) 281-96.

[18]. Vieillard P., Ramırez S., Bouchet A., Cassagnabere A., Meunier A., Jacquot E., Alteration of the Callovo-Oxfordian clay from Meuse-Haute Marne Underground Laboratory (France) by alkaline solution: II. Modelling of mineral reactions. Applied Geochemistry,19-11, (2004) 1699-1709.

[19]. Pekarek, V. and Milan M., Historical Background of Inorganic Ion Exchangers, their Classification, and Present Status. Inorganic Ion Exchangers in Chemical Analysis (eds. M. Qureshi and KG Varshney), CRC Press, Boca Raton, FL, 1991: pp 1-32.

[20]. Van Olphen H. and Fripiar J. J., Data Handbook for Clay Materials and Other Non-Metallic Minerals. Soil Science,131-1, (1981) 62-62.

[21]. Van der Marel H. W. and.Beutelspacher H., Atlas of infrared spectroscopy of clay minerals and their admixtures. Elsevier Publishing Company, (1976) pp 404.

[22]. Brindley G. W. and Brown G., Quantitative X-ray mineral analysis of clays. Crystal structures of clay minerals and their X-ray identification, 5-1, (1980) 411-438.

[23]. Brown, G., and Brindley, G. W. (Eds.), Crystal structures of clay minerals and their $\mathrm{X}$-ray identification, London: Mineralogical Society, Vol. 5, (1980) pp. 305-360.

[24]. Grim R. E., Clay Mineralogy. Soil Science, 76-4, (1953) 317-327.

[25]. Kamel N. and Navratil J., Migration of $134 \mathrm{Cs}$ in unsaturated soils at a site in Egypt. Journal of radioanalytical and nuclear chemistry. 254-3, (2002) 421-430.

[26]. Wahlberg J. S. and Fishman M. J., Adsorption of cesium on clay minerals. US Government Printing Office; 1962. 
Washington. Available at: https://pubs.usgs.gov/bul/1140a/report.pdf

[27]. Read D., Rabey B., Black S., Glasser F.P., Grigg C., Street A., Implementation of a strategy for managing radioactive scale in the China Clay industry. Minerals engineering. 17-2, (2004) 293-304. 